\title{
Kecukupan Modal, Pembiayaan Bermasalah, dan Efisiensi Operasional Sebagai Determinan dari Profitabilitas Bank Muamalat Indonesia Periode 2012-2017
}

\author{
Yoni Elmadwita \& Novi Mubyarto \\ Pascasarjana UIN Sulthan Thaha Saifuddin Jambi, Indonesia \\ E-mail: elmadwitayoni@gmail.com
}

\begin{abstract}
This research aims to analyze the effect of capital adequacy, financing risk, and operational efficiency on the profitability of Bank Muamalat Indonesia. This research uses a quantitative descriptive approach, the object of research is the Capital Adequacy Ratio (CAR / KPMM) as a proxy for capital adequacy, Non-Performing Financing (NPF) as a proxy for financing risk, Operational Costs Operating Income (BOPO / REO) as a proxy for operational efficiency, and Return on Assets (ROA) as a proxy for profitability. The research subjects are the annual and quarterly financial reports of PT. Bank Muamalat Indonesia for the period 2012 - 2017. Methods of data analysis using multiple linear regression. The results showed that CAR had no significant effect on ROA. Meanwhile, NPF and BOPO have a negative and significant effect on ROA.
\end{abstract}

Keywords: Capital adequacy, financing risk, operational efficiency, and profitability.

\begin{abstract}
Abstrak: Penelitian ini bertujuan untuk menganalisis pengaruh kecukupan modal, pembiayaan bermasalah, dan efisiensi operasional terhadap profitabilitas Bank Muamalat Indonesia. Penelitian menggunakan pendekatan deskriptif kuantitatif, Objek penelitian adalah Capital Adequacy Ratio (CAR/KPMM) sebagai proksi dari kecukupan modal, Non-Performing Financing (NPF) sebagai proksi dari pembiayaan bermasalah, Biaya Operasional Pendapatan Operasional (BOPO/REO) sebagai proksi dari efisiensi operasional dan Return on Asset (ROA) sebagai proksi dari profitabilitas. Subjek penelitian adalah laporan keuangan tahunan (Annual Report) dan triwulanan PT. Bank Muamalat Indonesia periode 2012 - 2017. Metode analisis data menggunakan regresi linier berganda. Hasil penelitian diketahui bahwa CAR tidak berpengaruh signifikan terhadap ROA. Sementara itu, NPF dan BOPO mempunyai pengaruh negatif dan signifikan terhadap ROA.
\end{abstract}

Kata-kata kunci: Kecukupan modal, pembiayaan bermasalah, efisiensi operasional, dan profitabilitas.

\section{Pendahuluan}

Peran perbankan syariah dalam aktifitas ekonomi di Indonesia dianggap cukup penting, Otoritas Jasa Keuangan (OJK) mempublikasikan dalam snapshot perbankan syariah bahwa "aset perbankan syariah tahun 2017 tercatat sebesar Rp 435,02 triliun meskipun OJK optimistis aset perbankan 
syariah diyakini akan terus bertumbuh, akan tetapi market sharenya terhadap total aset perbankan nasional 7.523,93 triliun tahun 2017 hanya baru mencapai 5,78 persen".' Selanjutnya Bank Muamalat Indonesia yang merupakan bank syariah pertama beroperasi di Indonesia sampai akhir tahun 2017 hanya memiliki total aset sebesar Rp 61,70 triliun atau 14,18 persen dari total aset bank syariah atau 0,82 persen terhadap total aset perbankan nasional.

Tabel. 1. Aset Perbankan Konvensional dan Syariah, Perbankan Syariah dan Bank Muamalat Indonesia Tahun 2017

\begin{tabular}{|l|c|c|c|}
\hline \multicolumn{1}{|c|}{ Kelompok Bank } & $\begin{array}{c}\text { Total Aset } \\
\text { (Rp Triliun) }\end{array}$ & $\begin{array}{c}\text { Proporsi Aset } \\
\text { terhadap Bank } \\
\text { Konvensional dan } \\
\text { Syaraih } \\
(\%)\end{array}$ & $\begin{array}{c}\text { Proporsi Aset } \\
\text { terhadap Bank } \\
\text { Syariah } \\
(\%)\end{array}$ \\
\hline $\begin{array}{l}\text { Bank Konvensional dan Syariah } \\
\text { (BUK, BUS dan BPR/S) }\end{array}$ & $7.523,93$ & 5,78 & \\
\hline $\begin{array}{l}\text { Bank Syariah } \\
\text { (BUS, UUS dan BPRS) }\end{array}$ & 435,02 & 0,82 & 14,18 \\
\hline Bank Muamalat Indonesia & 61,70 & & \\
\hline
\end{tabular}

Sumber: 0JK snapshot perbankan syariah (data diolah).

Data diatas menunjukkan bahwa peranan perbankan syariah terhadap perbankan nasional belumlah signifikan. Untuk dapat menjalankan fungsi dengan baik, kinerja bank secara keseluruhan harus terjaga. Bank syariah yang sehat adalah bank yang tidak saja dapat menjalankan fungsi-fungsi yang melekat padanya dengan baik, tetapi juga selalu menjaga prinsip-prinsip syariah dalam melaksanakan kegiatan operasionalnya. ${ }^{2}$ Bank pada umumnya juga selalu mengukur tingkat kesehatannya, faktor-faktor penilaian tersebut berdasarkan Peraturan Bank Indonesia No. 9/1/PBI/2007 tentang sistem penilaian tingkat kesehatan bank umum berdasarkan prinsip syariah, pasal 3 diantaranya mencakup permodalan, kualitas asset, manajemen, rentabilitas, likuiditas, dan sensitivitas terhadap resiko pasar. ${ }^{3}$

Penelitian ini mengambil objek Bank Muamalat Indonesia sebagai sampel penelitian, Dalam penelian ini indikator-indikator pengukuran yang digunakan adalah komponen faktor Modal (Kecukupan Modal/CAR), Kualitas Aset, Pembiayaan Bermasaklah (Non-Performing Financing) dan komponen faktor Rentabilitas (Profitabilitas, Efisiensi Operasional/BOPO). Dari data dokumentasi bank muamalat Indonesia selama periode 2012 - 2017 yang tersedia pada laporan keuangan tahunan Bank Muamalat Indonesia dan Statistik Perbankan Syariah (SPS OJK) secara spesifik dapat dilihat sebagaimana pada table berikut:

1 Snapshot Perbankan Syariah Indonesia, OJK, diakses melalui https://www.ojk.go.id, pada tgl 10 Oktober 2018.

${ }^{2}$ Kasmir. Dasar-Dasar perbankan, Edisi Revisi, Jakarta: Raja Grafindo Persada, 2012.

3 Peraturan Bank Indonesia No. 9/1/PBI/2007 tentang sistem penilaian tingkat kesehatan bank umum berdasarkan prinsip Syariah, 2007. 
Tabel. 2. Rasio ROA, CAR, NPF, dan BOPO Bank Muamalat dan Rata-Rata Industri Perbankan Syariah Periode 2012 - 2017

\begin{tabular}{|c|c|c|c|c|c|c|c|}
\hline \multirow{2}{*}{ Uraian } & \multicolumn{6}{|c|}{ Rasio/ Tahun } & \multirow{2}{*}{$\begin{array}{l}\text { Rata' } \\
\text { Rasio }\end{array}$} \\
\hline & 2012 & 2013 & 2014 & 2015 & 2016 & 2017 & \\
\hline ROA & 1,54 & 0,5 & 0,17 & 0,2 & 0,22 & 0,11 & 0,46 \\
\hline $\begin{array}{l}\text { ROA Rata" } \\
\text { Industri } \\
\end{array}$ & 2,14 & 2 & 1,19 & 1,15 & 1,2 & 1,55 & 1,54 \\
\hline CAR/KPMM & 11,57 & 14,05 & 13,91 & 12 & 12,74 & 13,62 & 12,98 \\
\hline \begin{tabular}{l|} 
CAR/KPMM Rata" \\
Industri
\end{tabular} & 14,13 & 14,42 & 15,74 & 15,02 & 16,63 & 17,91 & 15,64 \\
\hline NPF & 2,09 & 4,69 & 6,55 & 7,11 & 3,38 & 4,43 & 4,71 \\
\hline $\begin{array}{l}\text { NPF Rata" } \\
\text { Industri } \\
\end{array}$ & 2,22 & 2,62 & 3,75 & 3,94 & 3,96 & 3,44 & 3,32 \\
\hline BOPO/REO & 84,47 & 93,86 & 97,33 & 97,36 & 97,76 & 97,68 & 94,74 \\
\hline \begin{tabular}{|l|} 
BOPO/REO Rata" \\
Industri
\end{tabular} & 74,97 & 78,21 & 88,58 & 90,21 & 89,54 & 84,53 & 84,34 \\
\hline
\end{tabular}

Sumber: Annual Report PT. Bank Muamalat Indonesia dan SPS 0JK (data diolah).

Salah satu rasio yang dapat dipergunakan oleh bank untuk mengukur tingkat profitabilitas adalah Return on Assets (ROA). "ROA mencerminkan kemampuan manajemen bank dan seberapa efektif suatu bank dalam mengelola asetnya untuk menghasilkan suatu keuntungan". ${ }^{4}$ Bank Indonesia lebih cenderung melihat ROA sebagai representasi dari profitabilitas suatu bank karena Bank Indonesia lebih mengutamakan nilai profitabilitas yang diukur dengan asset yang dananya sebagian besar berasal dari dana simpanan masyarakat. 5

Berdasarkan pada Tabel. 2. terlihat bahwa pada tahun 2012 rasio ROA Bank Muamalat Indonesia dapat mencapai 1,54 persen, akan tetapi pada periode berikutnya terus mengalami penurunan hingga 0,11 persen pada tahun 2017. Selanjutnya, jika dibandingkan dengan nilai rata-rata ROA Industri Perbankan Syariah selama periode 2012 - 2017 juga mengalami trend penurunan, yaitu sebesar 2,14 persen pada tahun 2012, menjadi 1,55 persen pada tahun 2017. Meskipun sama-sama mengalami penurunan, namun jika dibandingkan besaran rata-rata rasio ROA maka Industri Perbankan Syariah masih jauh lebih tinggi dibandingkan dengan Bank Muamalat. ROA Bank Muamalat Indonesia yang telah dicapai baik ROA setiap tahun selama periode 2012 - 2017 maupun ROA rata-rata ternyata berada pada peringkat 4 (empat), menurut kriteria penilaian peringkat $(0 \%<\mathrm{ROA} \leq$ $0,5 \%$ ) belumlah cukup baik, karena angka tersebut belum mencapai standar

${ }^{4}$ Lampiran Surat Edaran Bank Indonesia No.9/24/DPbs/ tahun 2007 Perihal. Sistim penilaian tingkat kesehatan bank umum berdasarkan prinsip Syariah, 2007.

5 Lukman. Manajemen Perbankan, Edisi Kedua, Cetakan Kedua, Bogor: Ghalia Indonesia, 2005. 
ukuran yang ditetapkan oleh Bank Indonesia maupun 0JK yaitu peringkat 1 $(\mathrm{ROA}>1,5 \%)^{6}$

Secara teoritis faktor yang dinilai menentukan profitabilitas perbankan adalah rasio kecukupan modal atau CAR. ${ }^{7}$ Jika dilihat pada table 1.2. CAR Bank Muamalat Indonesia selama periode 2012 - 2017 adalah ratarata sebesar 12,98 persen, nilai ini lebih rendah dari rasio rata-rata industri perbankan syariah yaitu sebesar 15,64 persen. Meskipun rasio CAR Bank Muamalat Indonesia berada lebih baik diatas rasio angka standar ukuran CAR dalam hal ini Kewajiban Penyediaan Modal minimum (KPMM) bank kriteria penilaian peringkat yang ditetapkan oleh Bank Indonesia dan OJK yaitu peringkat $1(\mathrm{CAR} \geq 12,00)^{8}$, akan tetapi belum menunjukkan kestabilan.

Faktor penting lainnya yang menentukan adalah biaya operasional atau BOPO yang menggambarkan keefisienan dalam operasional bank. ${ }^{9}$ Bank yang produktif dan efisien harus dapat menjaga biaya operasional mereka tetap minimum. Jika semakin besar jumlah biaya operasional (BOPO), maka semakin rendah ROA. Mengacu pada Tabel 1.2 di atas, BOPO rata-rata Bank Muamalat Indonesia selama periode 2012 - 2017 adalah sebesar 94,74 persen, angka tersebut masih lebih tinggi dari BOPO rata-rata industri perbankan syariah yaitu 84,34 persen. Hal ini mengindikasikan bahwa tingkat inefisiensi yang dihadapi Bank Muamalat Indonesia cukup tinggi. BOPO sebesar 94,74 persen berada pada peringkat 5 (lima) yaitu REO > 89\%, sedangkan menurut standar ukuran REO yang ditetapkan oleh Bank Indonesia dan OJK kriteria penilaian peringkat 1 (satu) adalah REO $\leq 83 \% .^{10}$

Pengelolaan pembiayaan sangat diperlukan oleh bank, mengingat fungsi pembiayaan sebagai penyumbang pendapatan bagi bank syariah, pembiayaan yang disalurkan selain menghasilkan keuntungan sebaliknya juga berpotensi menimbulkan risiko. Risiko tersebut dapat berupa pembiayaan bermasalah atau Non-Performing Financing (NPF), NPF tinggi dapat menjadi salah satu ancaman bagi bank karena dapat mengurangi modal bank. NPF Bank Muamalat Indonesia di tahun 2012 sebesar 2,09 persen lebih kecil dari NPF rata-rata industri perbankan syariah, namun terjadi peningkatan hingga 4,43 persen pada tahun 2017. Selama periode 2012 - 2017 NPF Bank Muamalat Indonesia sangat berfluktuatif dan cenderung lebih besar dari NPF rata-rata industri perbankan syariah. Sedangakan NPF rata-rata sebesar 4,71 persen, angka tersebut masih lebih tinggi dari NPF rata-rata industri perbankan syariah yaitu 3,32. Hal ini

6 Lukman. Manajemen Perbankan,.

7 Chowdhury, M. A. F., \& Rasid, M. E. S. M, The determinants of the profitability of Islamic banks: a cross-sectional study from Asia and Africa, International Journal of Business and Globalisation, 15(3), 2015, hlm. 375-388.

${ }^{8}$ Lampiran Surat Edaran Bank Indonesia No.9/24/DPbs/ tahun 2007, Perihal Sistim penilaian tingkat kesehatan bank umum berdasarkan prinsip syariah.

${ }_{9}$ Abdillah, R., Hosen, M. N., \& Muhari, S, The Determinants Factor of Islamic Bank's Profitability and Liquidity in Indonesia. Knowledge Horizons Economics, 8(2), 2016, hlm.140.

${ }^{10}$ Lampiran Surat Edaran Bank Indonesia No.9/24/DPbs/ tahun 2007 Perihal. Sistim penilaian tingkat kesehatan bank umum berdasarkan prinsip syariah. 
mengindikasikan bahwa tingkat permasalahan pembiayaan yang dihadapi Bank Muamalat Indonesia cukup tinggi dan tidak begitu baik, NPF rata-rata Bank Muamalat Indonesia sebesar 4,71 persen tersebut berada pada peringkat 2 (dua) yaitu $2 \% \leq \mathrm{NPF}<5 \%$, sedangkan kriteria peringkat 1 (satu) adalah NPF < 2\% menurut standar ukuran NPF yang ditetapkan oleh Bank Indonesia dan OJK. ${ }^{11}$

Peranan, perkembangan dan perubahan sebagaimana dijelaskan pada deskripsi data diatas menunjukkan terdapat gejala-gejala yang mengindikasikan adanya ketidakstabilan kinerja Bank Muamalat Indonesia dalam operasinalnya khususnya kinerja keuangan untuk mendapatkan profit. Sesuai dengan fenomena yang telah diuraikan di atas, maka tujuan dari penelitian adalah: untuk mengetahui bagaimana pengaruh Kecukupan Modal, Pembiayaan Bermasalah dan Efisiensi Operasional Terhadap Profitabilitas Bank Muamalat Indonesia. Selanjutnya dilakukan identifikasi terhadap variabel manakah yang mempunyai pengaruh paling dominan terhadap Profitabilitas Bank Muamalat Indonesia tahun 2012 - 2017.

\section{Hubungan Kecukupan Modal (CAR) \& Profitabilitas (ROA)}

Capital Adequacy Ratio (CAR) merupakan rasio kecukupan modal yang menunjukkan kemampuan bank dalam menyediakan dana untuk keperluan ekspansi usaha serta menampung kemungkinan risiko kerugian yang diakibatkan dalam operasional bank. ${ }^{12}$ Semakin besar rasio tersebut maka semakin baik kemampuan bank untuk menanggung risiko dari setiap pembiayaan macet atau bermasalah. ${ }^{13}$ Sementara itu, disisi lain jika CAR dikelola dengan manajemen yang baik maka bank tersebut tidak saja mampu membiayai kegiatan operasionalnya dan menutupi penurunan aktiva, akan tetapi bank juga bisa melakukan pengembangan usaha sehingga memberikan kontribusi yang cukup besar bagi profitabilitas.

Untuk dapat berkembang secara sehat dan mampu bersaing dalam perbankan internasional maka permodalan bank harus senantiasa mengikuti standar ukuran yang berlaku secara internasional. Menurut standar Banking for International Sattlements (BIS), ukuran minimal dari CAR adalah sebesar 8\%.14 Sejalan dengan standar tersebut, dalam rangka paket deregulasi maka pada tanggal 29 Februari 1991 Bank Indonesia (BI) mewajibkan setiap bank umum menyediakan modal minimum sebesar $8 \%$ dari total aktiva tertimbang menurut risiko (ATMR).

11 Lampiran Surat Edaran Bank Indonesia No.9/24/DPbs/ tahun 2007 Perihal. Sistim penilaian tingkat kesehatan bank umum berdasarkan prinsip Syariah, 2007.

12 Fenandi Bilian dan Purwanto, Analisis Pengaruh CAR, NIM, BOPO, dan LDR Terhadap Profitabilitas Bank Persero, FIRM Journal of Managemen Studies, Vol. 2, No. 1, 2017, hlm. $155-168$.

13 Tarmizi Achmad dan Willyanto Kartiko Kusuno, Analisis Rasio-rasio Keuangan Sebagai Prediktor dalam Memprediksi Potensi Kebangkrutan Perbankan di Indonesia, Media Ekonomi dan Bisnis, Vol. XV, No. 1, 2003.

14 Dendawijaya Lukman, Manajemen Perbankan, Ghalia Indonesia: Jakarta, 2003. 
Hasil studi dari beberapa penelitian sebelumnya Mawardi15; Putri, Wiagustini, dan Abundanti ${ }^{16}$, menunjukkan bahwa kecukupan modal (CAR) berpengaruh signifikan terhadap profitabilitas (ROA). Namun hasil ini berbeda dengan hasil temuan dari Pinasti dan Mustikawati ${ }^{17}$; Ary Natalina, C. Widi Pratiwi, dan Andi Nariya ${ }^{18}$; dan Imas Maisaroh ${ }^{19}$, yang menyatakan bahwa CAR tidak berpengaruh signifikan terhadap ROA.

\section{Ha1: Capital Adequacy Ratio Berpengaruh Signifikan terhadap Profitabilitas}

CAR/KPMM dapat diperoleh dengan membagi total modal dengan aset tertimbang menurut risiko (ATMR), tujuannya adalah untuk mengukur kecukupan modal bank dalam menyerap kerugian dan pemenuhan ketentuan KPMM yang berlaku. ${ }^{20} \mathrm{CAR} / \mathrm{KPMM}$ dihitung dengan rumus seperti di bawah ini (Lampiran SE BI No.13/30/DPNP Tgl 16 Desember 2011). ${ }^{21}$ Rasio ini dapat dirumuskan sebagai berikut:

$$
C A R=\frac{M O D A L B A N K}{\text { TOTAL ATMR }} \times 100 \%
$$

Dengan kriteria penilaian peringkat sebagai berikut:

Peringkat $1=\mathrm{KPMM} \geq 12 \%$ (bank tergolong sangat baik dan mampu mengatasi pengaruh negatif kondisi perekonomian dan industri keuangan).

Peringkat $2=9 \% \leq \mathrm{KPMM}<12 \%$ (bank tergolong baik dan mampu mengatasi pengaruh negatip kondisi perekonomian dan industri keuangan namun bank masih memiliki kelemahankelemahan minor yang dapat segera diatasi oleh tindakan rutin).

15 Wisnu Mawardi, Analisis Faktor-faktor yang Mempengaruhi Kinerja Keuangan Bank Umum di Indonesia (Studi Kasus Pada Bank Umum dengan Total Assets Kurang dari 1 Trilliun), Jurnal Bisnis Strategi, Vol. 3, No. 3, 2005.

16 Ni Kadek Alit Pradina Putri, Luh Putu Wiagustini, dan Ni Nyoman Abundanti. Pengaruh NPL, CAR dan BOPO Terhadap Profitabilitas pada BPR di Kota Denpasar. Jurnal Manajemen Unud, Vol. 7, No. 11, 2018, hlm. 6212 - 6238.

17 Wildan Farhat Pinasti dan RR, Indah Mustikawati, Pengaruh CAR, BOPO, NPL, NIM dan LDR Terhadap Profitabilitas Bank Umum Periode 2011-2015, Jurnal Nominal, Vol VII, No 1, 2018, hlm. 126-142.

18 Ary Natalina, C. Widi Pratiwi, dan Andi Nariya, Analisis Capital Adequacy Ratio (CAR) dan Aktiva Tetap Terhadap Modal (ATTM) Terhadap Profitabilitas pada PT. Bank Permata, TBK, UG Jurnal, Vol. 7, No. 06, 2013, hlm. 13-18.

19 Imas Maisaroh, Analisis Rasio Keuangan Terhadap Kinerja Keuangan Perbankan yang Terdaftar di BEI Periode 2009-2013, Jurnal Akuntansi dan Bisnis, Vol 15, No 1, 2015, hlm. 13 - 22.

${ }^{20}$ Lampiran Surat Edaran Bank Indonesia No.9/24/DPbs/ tahun 2007 Perihal. Sistim penilaian tingkat kesehatan bank umum berdasarkan prinsip syariah.

21 Lampiran SE BI No.13/30/DPNP Tgl 16 Desember 2011. 


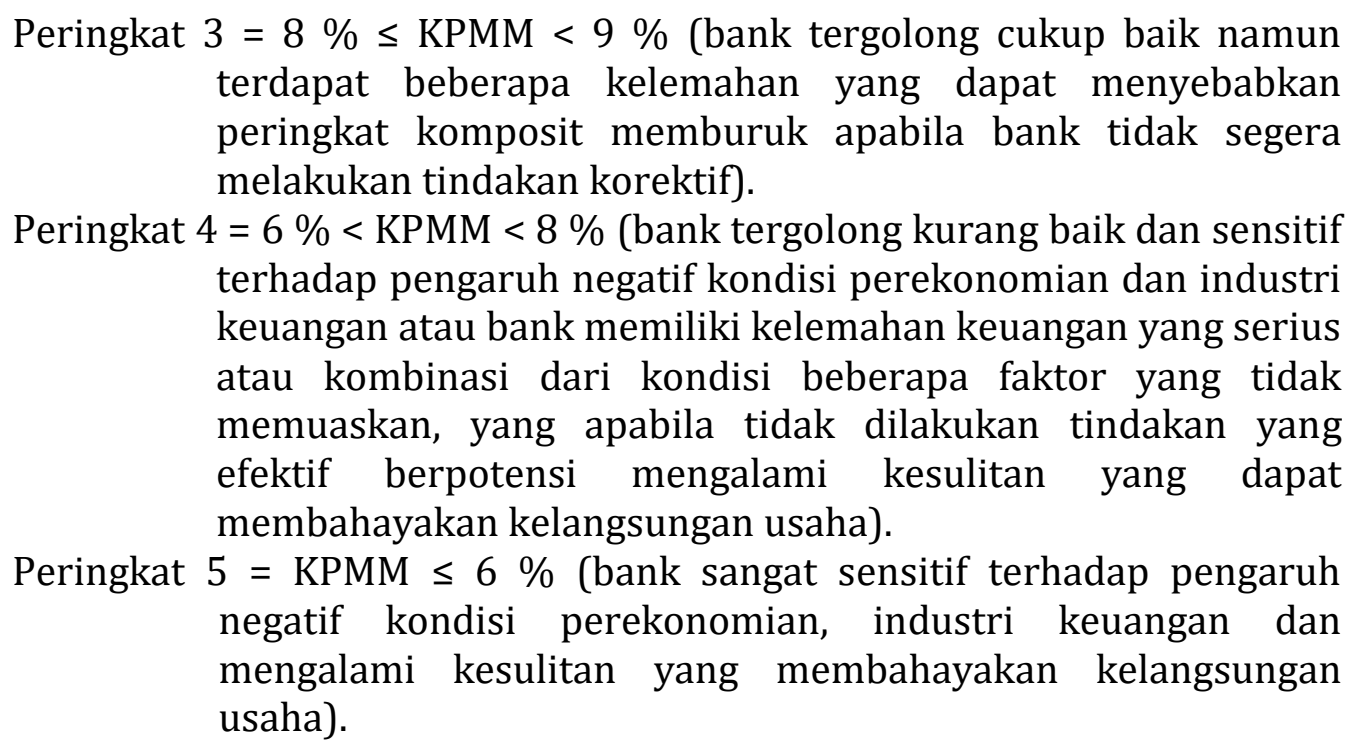

\section{Hubungan Pembiayaan Bermasalah (NPF) dan Profitabilitas (ROA)}

Not Performing Financing (NPF) merupakan rasio yang digunakan untuk mengukur kemampuan bank dalam mengelola pinjaman bermasalah yang diberikan oleh bank. ${ }^{22}$ Risiko pinjaman bermasalah merupakan salah satu risiko usaha bank, sebagai akibat dari tidak dilunasinya kembali pinjaman yang diberikan oleh pihak bank kepada debitur. NPF yang tinggi akan memperbesar biaya, sehingga berpotensi terhadap kerugian bank. Semakin tinggi rasio ini maka akan semakin buruk kualitas pinjaman bank yang menyebabkan jumlah pinjaman bermasalah semakin besar, dan oleh karena itu bank harus menanggung kerugian dalam kegiatan operasionalnya sehingga berpengaruh terhadap penurunan laba (ROA) yang diperoleh bank $^{23}$. Menurut Peraturan Bank Indonesia Nomor 6/10/PBI/2004 tanggal 12 April 2004 tentang Sistem Penilaian Tingkat Kesehatan Bank Umum, menetapkan bahwa rasio kredit bermasalah (NPL) adalah sebesar 5\%. Dengan demikian dapat dirumuskan bahwa pembiayaan bermasalah (NPF) berpengaruh negatif signifikan terhadap profitabilitas (ROA).

Beberapa studi sebelumnya menunjukkan adanya pengaruh negatif antara pembiayaan bermasalah (NPF) terhadap Profitabilitas (ROA). ${ }^{24}$ Studi Lenny Yanthiani menemukan hal yang sama bahwa NPF berpengaruh negatif

${ }^{22}$ Muhammad Yusuf Wibisono dan Salamah Wahyuni, Pengaruh CAR, NPF, BOPO, FDR, Terhadap ROA yang dimediasi oleh NOM, Jurnal Bisnis \& Manajemen, Vol. 17, No. 1, 2017, hlm. $41-62$.

${ }^{23}$ Kasmir, Manajemen Perbankan, Jakarta: Raja Grafindo Persada, 2004.

24 Johar Manikam dan Muchamad Syafruddin, Analisis Pengaruh Capital Adequacy Ratio (CAR), Net Interest Margin (NIM), Loan to Deposit Ratio (LDR) dan BOPO Terhadap Profitabilitas Bank Persero di Jambi Periode 2005-2012, Vol. 2, No. 4, 2013, hlm. 1-10. 
signifikan terhadap ROA. ${ }^{25}$ Hasil ini bertentangan dengan hasil penelitian yang dilakukan Ponttie Prasnanugraha yang menunjukkan adanya pengaruh yang positif antara Non Performing Financing (NPF) terhadap Return on Asset (ROA). ${ }^{26}$ Selanjutnya Lemiyana dan Erdah Litriani dalam studi mereka menemukan bahwa Non Performing Financing (NPF) and Financing to Deposit Ratio (FDR), has no influence to Return on Asset (ROA). ${ }^{27}$ Terdapat research gap dari penelitian sebelumnya, maka perlu dilakukan penelitian lanjutan pengaruh Non Performing Financing (NPF) terhadap Return on Asset (ROA).

\section{Ha2: Non-Performing Financing Berpengaruh Signifikan Terhadap Profitabilitas}

Non-Performing Financing (NPF) dapat dihitung dengan rumus (Lampiran SE BI No.13/30/DPNP Tgl 16 Desember 2011). ${ }^{28}$

$$
N P F=\frac{P E M B I A Y A A N(K L, D, M)}{\text { TOTAL PEMBIAYAAN }} \times 100 \%
$$

Dengan kriteria penilaian peringkat sebagai berikut:

Peringkat $1=\mathrm{NPF}<2 \%$ (bank tergolong sangat baik dan mampu mengatasi pengaruh negatif kondisi perekonomian dan industri keuangan).

Peringkat $2=2 \% \leq \mathrm{NPF}<5 \%$ (bank tergolong baik dan mampu mengatasi pengaruh negatip kondisi perekonomian dan industri keuangan namun bank masih memiliki kelemahankelemahan minor yang dapat segera diatasi oleh tindakan rutin).

Peringkat $3=5 \% \leq \mathrm{NPF}<8 \%$ (bank tergolong cukup baik namun terdapat beberapa kelemahan yang dapat menyebabkan peringkat komposit memburuk apabila bank tidak segera melakukan tindakan korektif.

Peringkat $4=8 \% \leq \mathrm{NPF}<12 \%$ (bank tergolong kurang baik dan sensitif terhadap pengaruh negatif kondisi perekonomian dan industri keuangan atau bank memiliki kelemahan keuangan yang serius atau kombinasi dari kondisi beberapa faktor yang tidak memuaskan, yang apabila tidak dilakukan tindakan yang

25 Lenny Yanthiani, Pengaruh Non-Performing Financing (NPF) dan Financing to Deposit rtio (FDR) Terhadap Return on asset (ROA) di PT. bank Jabar Banten Syariah Kantor Pusat. Jurnal Akuntansi Bisnis dan Ekonomi, Vol. 5 No. 1, 2019.

26 Ponttie Prasnanugraha. Analisis Pengaruh Rasio-rasio Keuangan Terhadap Kinerja Bank Umum di Indonesia (Studi Empiris Bank-bank Umum Yang Beroperasi Di Indonesia. Tesis, 2007.

${ }^{27}$ Lemiyana dan Erdah Litriani, Pengaruh NPF, FDR, BOPO Terhadap Return on Asset (ROA) pada Bank Umum Syariah. Economic, Vol. 2. No.1, 2016.

${ }^{28}$ Lampiran SE BI No.13/30/DPNP Tgl 16 Desember 2011. 
efektif berpotensi mengalami kesulitan yang dapat membahayakan kelangsungan usaha).

Peringkat $5=\mathrm{NPF} \geq 12 \%$ (bank sangat sensitif terhadap pengaruh negatif kondisi perekonomian, industri keuangan dan mengalami kesulitan yang membahayakan kelangsungan usaha).

\section{Hubungan Efisiensi Operasional (BOPO) dan Profitabilitas (ROA)}

BOPO (Biaya Operasional terhadap Beban Operasional), merupakan rasio efisiensi yang digunakan untuk mengukur kemampuan manajemen bank dalam mengendalikan biaya operasional terhadap pendapatan operasional. BOPO yang tinggi dan terus meningkat meng-indikasikan bahwa bank tidak efektif dan tidak efisien dalam mengelola sumberdaya (resources) yang dimilikinya, dan ini dapat memperkecil tingkat profitabilitas. Sementara itu, semakin kecil rasio ini berarti semakin efisien biaya operasional yang dikeluarkan bank yang bersangkutan sehingga kemungkinan suatu bank dalam kondisi bermasalah semakin kecil. ${ }^{29}$

Penelitian yang dilakukan oleh Defri menemukan bahwa BOPO berpengaruh negatif dan signifikan terhadap ROA pada perusahaan perbankan yang terdaftar di BEI. ${ }^{30}$ Begitu pula hasil studi dari Ningsukma Hakiim dan Haqiqi Rafsanjani yaitu BOPO secara parsial berpengaruh negatif dan signifikan terhadap ROA. ${ }^{31}$

\section{Ha3: BOPO Berpengaruh Signifikan Terhadap Profitabilitas}

Dalam surat edaran Bank Indonesia No.9 tahun 2007 disebutkan efisiensi operasional diukur dengan membandingkan total biaya operasi terhadap total pendapatan operasi (BOPO) yang disebut juga rasio efisiensi operasional (REO), rasio ini bertujuan untuk mengukur efisiensi kegiatan operasional bank syariah. ${ }^{32}$ Biaya operasional dihitung berdasarkan penjumlahan dari total beban bunga dan total beban operasional lainnya. Pendapatan operasional adalah penjumlahan dari total pendapatan bunga

29 Yuliani, Hubungan Efisiensi Operasional dengan Kinerja Profitabilitas pada Sektor Perbankan yang GO Publik di Bursa Efek Jakarta, Jurnal Manajemen \& Bisnis Sriwijaya, Vol. 5, No. 10, 2007.

30 Defri, Pengaruh Capital Adequacy Ratio (CAR), Likuiditas dan Efisiensi Operasional Terhadap Profitabilitas Perusahaan Perbankan yang Terdaftar di BEI, Jurnal Manajemen, Vol. 01, No. 01, 2012.

31 Ningsukma Hakim dan Haqiqi Rafsanjani, Pengaruh Internal Capital Adequency Ratio (CAR), Financing to Deposit Ratio (FDR), dan Biaya Operasional per Pendapatan Operasional (BOPO) dalam Peningkatan Profitabilitas Industri Bank di Indonesia, Jurnal Perbankan Syariah, Vol. 1, No. 1, 2016.

32 Surat Edaran Bank Indonesia No.9/24/DPbs/ tahun 2007 Perihal. Sistim penilaian tingkat kesehatan bank umum berdasarkan prinsip syariah. 
dan total pendapatan operasional lainnya. Rasio ini dirumuskan sebagai berikut (SE BI No.3/30/DPNP tgl 14 Desember 2001):

$$
\text { BOPO }=\frac{\text { BIAYA OPERASIONAL }}{\text { PENDAPATAN OPERASIONAL }} \times 100 \%
$$

Dengan kriteria penilaian peringkat sebagai berikut :

Peringkat $1=$ REO $\leq 83 \%$ (bank tergolong sangat baik dan mampu mengatasi pengaruh negatif kondisi perekonomian dan industri keuangan).

Peringkat $2=83 \%<\mathrm{REO} \leq 85 \%$ (bank tergolong baik dan mampu mengatasi pengaruh negatip kondisi perekonomian dan industri keuangan namun bank masih memiliki kelemahankelemahan minor yang dapat segera diatasi oleh tindakan rutin).

Peringkat $3=85 \%<$ REO $\leq 87 \%$ (bank tergolong cukup baik namun terdapat beberapa kelemahan yang dapat menyebabkan peringkat komposit memburuk apabila bank tidak segera melakukan tindakan korektif).

Peringkat $4=87 \%<$ REO $\leq 89 \%$ (bank tergolong kurang baik dan sensitif terhadap pengaruh negatif kondisi perekonomian dan industri keuangan atau bank memiliki kelemahan keuangan yang serius atau kombinasi dari kondisi beberapa faktor yang tidak memuaskan, yang apabila tidak dilakukan tindakan yang efektif berpotensi mengalami kesulitan yang dapat membahayakan kelangsungan usaha).

Peringkat $5=$ REO > $89 \%$ (bank sangat sensitif terhadap pengaruh negatif kondisi perekonomian, industri keuangan dan mengalami kesulitan yang membahayakan kelangsungan usaha). 


\section{Metode}

Penelitian yang melatari tulisan ini menggunakan data sekunder dengan metode analisis kuantitatif. Untuk menguji hipotesis yang telah dirumuskan, maka penelitian ini menggunakan jenis penelitian explanatory research. Adapun fokus penelitian ini adalah untuk memprediksi dan menganalisis Pengaruh Kecukupan Modal, Pembiayaan Bermasalah, dan Efisiensi Operasional Terhadap Profitabilitas Bank Muamalat Indonesia. Metode analisis data yang dipilih adalah Metode Analisis Regresi Berganda.

\section{Hasil dan Pembahasan}

Untuk memenuhi kriteria model analisis regresi linier berganda yang best linear unbiased estimator artinya tidak bias atau nilai harapan dari estimator sama atau mendekati nilai parameter yang sebenarnya. Maka model estimasi harus memenuhi asumsi klasik, yaitu meliputi:

1. Uji Normalitas

Untuk mengetahui apakah data pada model regresi memiliki distribusi normal atau tidak digunakan Uji Normalitas. Pada penelitian ini digunakan uji One-Sample Kolmogorov-Smirnov Test, dengan dasar pengambilan keputusan apabila signifikansi hasil perhitungan data (Sig) $<5 \%$, maka data tidak berdistribusi normal dan apabila sebaliknya signifikansi hasil perhitungan data $>5 \%$ maka data berdistribusi normal.

Tabel 3. Uji Nomalitas One-Sample Kolmogorov-Smirnov Test

\begin{tabular}{ccc}
\hline & $\begin{array}{c}\text { Unstandardize } \\
\text { d Residual }\end{array}$ & Keterangan \\
\hline $\mathrm{N}$ & 24 & Data Berdistribusi \\
Test Statistic & .139 & Normal \\
Asymp. Sig. (2-tailed) & $.200^{\mathrm{c}, \mathrm{d}}$ & \\
\hline
\end{tabular}

Uji Normalitas. Berdasarkan hasil uji One-Sample KolmogorovSmirnov Test, diketahui bahwa nilai signifikansi "Asymp.Sig (2-tailed) sebesar 0,200 > 0,05. dan nilai kolmogorov-smirnov Z/Test Statistik sebesar 0,139 . Maka dapat disimpulkan bahwa data berdistribusi normal.

2. Uji Multikolinieritas

Uji Multikolinearitas Uji multikolinieritas dilakukan dengan menggunakan perhitungan Tolerance dan metode VIF (Variance Inflation Factor). ${ }^{33}$

33 Imam Ghozali, Aplikasi Analisis Multivariate Dengan Program SPSS, Semarang: Badan Penerbit Universitas Diponegoro, 2012, hlm. 105 - 106. 
Tabel 4. Hasil Uji Multikolinieritas

\begin{tabular}{lcc}
\hline Variabel & Tolerance & VIF \\
\hline CAR & .932 & 1.073 \\
NPF & .770 & 1.299 \\
BOPO & .789 & 1.268 \\
\hline
\end{tabular}

Sumber: Hasil Estimasi data sekunder.

Berdasarkan uji multikolinieritas pada tabel 5, hasil estimasi menunjukkan bahwa semua variabel bebas mempunyai nilai tolerance di atas 0,1 dan nilai VIF di bawah 10, sehingga dapat disimpulkan bahwa model regresi pada penelitian ini tidak terjadi multikolinieritas.

\section{Uji Heteroskedastisitas}

Uji Heteroskedastisitas model regresi yang baik adalah yang homoskedastisitas atau tidak terjadi heteroskedastisitas. ${ }^{34}$ Ada tidakmya gejala heteroskedasitas dalam penelitian ini di uji dengan menggunakan analisis Grafik Plot. ${ }^{35}$ Dasar pengambilan keputusan dalam uji heteroskedastisitas Grafik Plot adalah dengan memperhatikan pola pencar scatterplot, ditunjukkan dengan tidak ada pola yang jelas, serta titik-titik menyebar diatas dan dibawah angka 0 pada sumbu Y, itu dikatakan tidak terjadi heteroskedastisitas.

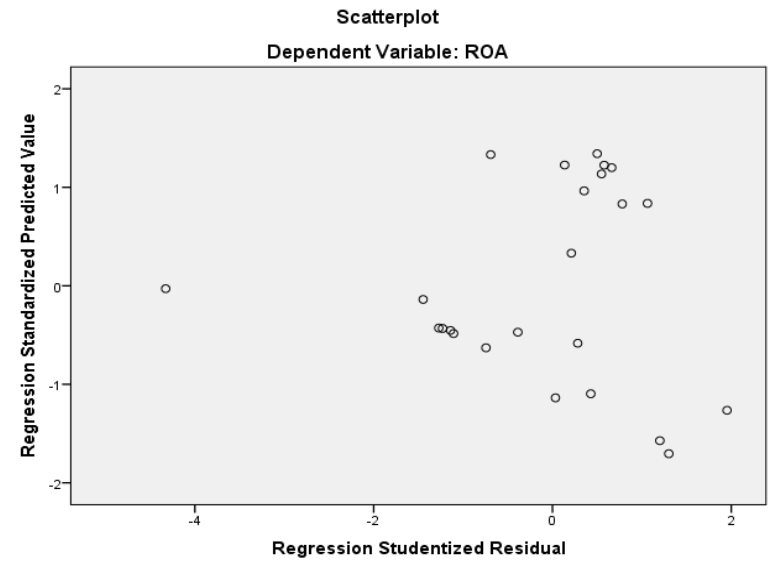

Gambar. 2 Grafik Scatterplot Uji Heteroskedastisitas

Berdasarkan gambar diatas dapat terlihat bahwa titik-titik menyebar diatas dan dibawah angka 0 pada sumbu Y, maka berdasarkan metode grafik scatterplot tidak terjadi heteroskedastisitas pada model regresi.

34 Imam Ghozali, Aplikasi Analisis Multivariate Dengan Program SPSS, Semarang: Badan Penerbit Universitas Diponegoro, 2012, 139.

35 Imam Ghozali, Aplikasi Analisis., hlm.139. 
4. Uji Autokorelasi

Model regresi yang baik adalah regresi yang bebas dari autokorelasi. ${ }^{36}$ Untuk mendeteksi ada tidaknya autokorelasi dalam penelitian ini dilakukan pengujian dengan menggunakan "Uji Runs Test".

Tabel 5. Hasil Uji Autokorelasi dengan Run Test

\begin{tabular}{lc}
\hline & Unstandardized Residual \\
\hline Total Cases & 24 \\
$\mathrm{Z}$ & -1.044 \\
Asymp. Sig. (2-tailed) & .297 \\
\hline
\end{tabular}

Sumber: Hasil Estimasi Data Sekunder

Berdasarkan hasil uji Run Test diketahui nilai Asyimp.Sig (2-tailed) sebesar 0,297 >0,05, maka dapat disimpulkan bahwa tidak terdapat gejala atau masalah autokorelasi data penelitian, sehingga analisis regresi linear dapat dilanjutkan.

\section{Hasil Analisis Regresi Linier Berganda}

Analisis regresi linear berganda digunakan untuk mengetahui pengaruh variabel independen (CAR, NPF dan BOPO) terhadap variabel dependen (ROA) dengan menggunakan persamaan linear. Hasil analisis regesi berganda dapat diketahui pada tabel berikut.

Tabel. 6. Hasil Uji t Regresi Linear Berganda

\begin{tabular}{llccccc}
\hline & Variabel & $\mathrm{B}$ & Std. Error & Beta & $\mathrm{t}$ & Sig \\
\hline 1 & (Constant) & 437.610 & 104.812 & & 4.175 & .000 \\
CAR & -.021 & .045 & -.050 & -.464 & .648 \\
NPF & -.266 & .045 & -.709 & -5.961 & .000 \\
& BOPO & -.025 & .009 & -.315 & -2.681 & .014 \\
\hline
\end{tabular}

Sumber: Hasil Estimasi Data Sekunder

Hasil pengujian masing-masing variabel dapat dijelaskan sebagai berikut:

Pengaruh Kecukupan Modal terhadap Profitabilitas

Berdasarkan pada hasil uji regresi pada tabel 9, hasil statistik uji t untuk variabel Kecukupan Modal (CAR) diperoleh nilai signifikansi sebesar 0,648 lebih besar dari toleransi kesalahan $\alpha=0,05$. Artinya variabel kecukupan modal (CAR) tidak berpengaruh signifikan terhadap profitabilitas (ROA) pada bank Muamalat.

Pengaruh negatif kecukupan modal (CAR) namun tidak signifikan terhadap Profitabilitas (ROA) mengindikasikan bahwa besar kecilnya CAR belum signifikan mempengaruhi besar kecilnya perolehan laba bank. Hal ini bisa saja terjadi karena kurangnya pemanfaatan modal untuk hal-hal yang

36 Imam Ghozali, Aplikasi Analisis Multivariate Dengan Program SPSS, Semarang: Badan Penerbit Universitas Diponegoro, 2012, hlm. 210. 
dapat menghasilkan laba, misalnya ekspansi kredit. Selain itu kemungkinan bank dalam beroperasi sangat menjaga besarnya modal, karena adanya regulasi yang mensyaratkan CAR minimal, mengakibatkan bank berusaha menjaga CAR yang dimiliki sesuai dengan ketentuan.

Nilai CAR diperoleh dari modal bank dibanding dengan ATMR. "ATMR adalah kredit yang diberikan kepada masyarakat oleh pihak bank. Jadi semakin besar ATMR maka akan menurunkan nilai dari CAR dan sebaliknya semakin kecil ATMR maka akan meningkatkan nilai CAR." 37 Disisi lain kredit yang diberikan kepada masyarakat dapat membuka kesempatan bank untuk memperoleh pendapatan dari bunga pinjaman yang diberikan. Demikian juga kemungkinan lain CAR berpengaruh negatif tidak signifikan terhadap ROA dikarenakan bank belum dapat memberikan pembiayaan yang optimal.

Hasil temuan penelitian ini sejalan dengan hasil penelitian yang dilakukan Medina Almunawwaroh, tentang "Analisis pengaruh kecukupan modal, kualitas aktiva produktif dan likuiditas terhadap kinerja bank umum syariah di Indonesia" dalam penelitiannya menunjukkan hasil bahwa CAR berpengaruh negatif terhadap profitabilitas. ${ }^{38}$

Pengaruh Risiko Pembiayaan terhadap Profitabilitas

Berdasarkan hasil uji regresi pada tabel 9, hasil statistik uji t untuk variabel Risiko Pembiayaan (NPF) diperoleh nilai signifikansi sebesar 0,000 lebih kecil dari nilai kesalahan $\alpha=0,05$. Artinya variabel Risiko Pembiayaan (NPF) berpengaruh signifikan terhadap profitabilitas bank muamalah. Koefisien regresi bernilai negatif sebesar -0,266 menunjukkan bahwa peningkatan risiko pembiayaan berdampak buruk pada penurunan tingkat profitabilitas bank Muamalat.

NPF mencerminkan jumlah pembiayaan bermasalah yang diterima bank dikarenakan kualitas pembiayaan yang buruk. Jika kualitas pembiayaan yang diberikan buruk maka akan meningkatkan risiko, karena bank harus menanggung kerugian dalam kegiatan operasionalnya, sehingga berpengaruh terhadap penurunan laba yang diperoleh bank. Tingginya rasio NPF yang dimiliki oleh bank juga akan berpengaruh terhadap nilai dan kualitas aset bank, hal itu akan berdampak pada nilai profitabilitas bank itu sendiri, karena dapat menyebabkan terganggunya kelancaran kegiatan usaha bank. Jika NPF naik, maka return on asset (ROA) akan menurun, begitu juga sebaliknya, jika NPF turun, maka return on asset (ROA) akan naik. NPF yang rendah mengindikasikan kinerja keuangan bank semakin baik.

Tingginya kasus pembiayaan bermasalah (Non-Performing Financing) pada perbankan, dapat disikapi dengan meningkatkan aktiva produktif dan menurunkan pendapatan dari bunga, hal itu dapat dilakukan karena aktiva

37 Lukman Dendawijaya, Manajemen Perbankan, Jakarta: Ghalia Indonesia, 2009, hlm. 52.

38 Medina Almunawwaroh, Analisis pengaruh kecukupan modal, kualitas aktiva produktif dan likuiditas terhadap kinerja bank umum syariah di Indonesia, Jurnal Akuntansi, Vol. 12, No. 1, 2017, hlm. 69 - 84. 
produktif adalah bagian dari asset yang dapat menanggulangi risiko, demikan juga dengan penurunan bunga dapat pula meminamalisir NPF.

Hasil temuan penelitian ini sejalan dengan hasil penelitian yang dilakukan oleh Sineba Arli Silvia, 2017 tentang "Pengaruh kualitas aset terhadap profitabilitas pada perbankan syariah di Indonesia" menunjukan hasil bahwa NPF berpengaruh negatif dan signifikan terhadap profitabilitas.

\section{Pengaruh Efisiensi Operasional terhadap Profitabilitas}

Berdasarkan hasil uji regresi pada tabel 9, hasil statistik uji t untuk variabel Efisiensi Operasional diperoleh nilai signifikansi sebesar 0,014 lebih kecil dari nilai kesalahan $\alpha=0,05$. Artinya kebijakan bank dalam menerapkan efisiensi operasional berpengaruh signifikan terhadap kemampuan menghasilkan profitabilitas. Sementara itu nilai koefisien regresi bernilai negatif sebesar $-0,025$ menunjukkan bahwa peningkatan risiko pembiayaan berdampak buruk secara signifikan terhadap penurunan tingkat profitabilitas bank Muamalat dan begitu pula sebaliknya. Hasil temuan ini juga menunjukkan bahwa kemapuan manajemen keuangan bank muamalah dalam mengendalikan biaya operasional sangat penting sebagai upaya meningkatkan laba perusahaan.

Jika rasio BOPO semakin kecil, maka kinerja perbankan akan meningkat seiring dengan meningkatnya return on asset (ROA). Semakin tinggi rasio BOPO maka dapat dikatakan kegiatan operasional yang dilakukan bank tidak efisien, karena semakin besar BOPO akan berakibat pada turunnya return on asset (ROA), sehingga kinerja perbankan menurun.

Peningkatan rasio BOPO dapat disebabkan karena tingginya biaya dana yang dihimpun dan rendahnya pendapatan bunga dari penanaman dana. Semakin besar BOPO, maka akan semakin kecil/menurun kinerja keuangan perbankan, begitu juga sebaliknya, bila BOPO semakin kecil, maka dapat disimpulkan bahwa kinerja keuangan perbankan semakin meningkat atau membaik. Demikian pula apabila semua kegiatan operasional yang dilakukan bank dapat berjalan secara efektif, efisien dan optimal beban operasional dapat diminimalisir maka kinerja keuangan bank akan meningkat.

Hasil temuan penelitian ini sejalan dengan hasil penelitian yang dilakukan oleh Sri Windarti Mokoagow dan Misbach Fuady tentang "Faktorfaktor yang mempengaruhi profitabilitas bank umum syariah di Indonesia" menunjukkan hasil bahwa REO berpengaruh negatif signifikan terhadap profitabilitas. ${ }^{39}$

39 Sri Windarti Mokoagow dan Misbach Fuady, Faktor - Faktor yang Mempengaruhi Profitabilitas Bank Umum Syariah di Indonesia, Jurnal EBBANK, Vol. 6, No. 1, 2015, hlm. 33 62. 


\section{Variabel yang paling dominan diantara variabel CAR, NPF dan BOPO yang Mempengaruhi Profitabilitas (Return on Assets)}

Berdasarkan pada hasil estimasi pada table 4 diatas terlihat bahwa variabel NPF adalah merupakan variabel yang paling besar pengaruhnya terhadap ROA. Hal tersebut dibuktikan dengan nilai koefisien beta sebesar -0,266 dengan signifikansi 0,000. Pengaruh NPF yang dominan dan signifikan menunjukan bahwa peran dari pembiayaan bermasalah terhadap perkembangan profitabilitas sangat menentukan, pengaruh yang dominan dan signifikan juga menunjukan bahwa nilai NPF harus terus diminimalisir. Besarnya pengaruh NPF terhadap ROA dipahami karena semakin tinggi NPF maka semakin besar risiko bank untuk menanggung risiko pembiayaan bermasalah. Jika nilai NPF tinggi maka bank tersebut di indikasikan tidak mampu meminimalisir risiko pembiayaan, NPF yang tinggi dapat mengurangi kesempatan untuk memperoleh profitabilitas.

\section{Penutup}

Berdasarkan hasil analisis dan pembahasan yang telah dijelaskan sebelumnya, maka simpulan dari penelitian ini adalah sebagai berikut: 1 . Kecukupan Modal tidak berpengaruh signifikan terhadap Profitabilitas, hal ini dibuktikan dengan nilai koefisien regresi sebesar 0,021 dan nilai signifikansi sebesar 0,648. 2. Risiko Pembiayaan berpengaruh negatif dan signifikan terhadap Profitabilitas, hal ini dibuktikan dengan nilai koefisien regresi sebesar -0,266 dan nilai signifikansi sebesar 0,000. 3. Efisiensi Operasional berpengaruh negatif dan signifikan terhadap Profitabilitas, hal ini dibuktikan dengan nilai koefisien regresi sebesar $-0,025$ dan nilai signifikansi sebesar 0,014 .

Temuan hasil penelitian menunjukkan bahwa Risiko Pembiayaan (NPF) merupakan rasio keuangan yang paling besar pengaruhnya dan paling signifikan terhadap perubahan laba (ROA), untuk itu manajemen muamalat Indonesia dalam memprediksi profitabilitas dalam hal ini Return On Assets (ROA) pada periode mendatang sebaiknya mempertimbangkan aspek risiko pembiayaan (NPF). Rasio pembiayaan bermasalah atau non performing financing (NPF) yang tinggi mengindikasikan bank tersebut berisiko, sehingga dalam pembiayaan bank dianjurkan untuk lebih berhati-hati untuk memenuhi permintan kredit karena dikhawatirkan terjadi peningkatan penunggakan dalam pembayaran kreditnya. Demikian juga dalam melakukan ekspansi pembiayaan harus terkendali sehingga bank tidak menanggung risiko yang besar, risiko pembiayaan yang besar dapat pula memperkecil kesempatan bank memperoleh pendapatan atau profitabilitas. NPF yang semakin tinggi menunjukkan semakin riskan dan kurangnya efektifitas bank dalam menyalurkan kredit sehingga hilangnya kesempatan bank untuk memperoleh profit. 
Agar bank selalu berada pada tingkat efisiensi yang bisa menghasilkan profit yang maksimal, hal tersebut dapat dilakukan diantaranya dengan meminimalkan biaya dan mengoptimalkan tingkat suku bunga yang dapat bersaing, dengan tingkat suku bunga yang bersaing selisih (spread) suku bunga antara bunga pinjaman dengan bunga simpanan yang merupakan pendapatan utama bank selalu terkontrol, sehingga kinerja yang dicapai selalu meningkat. "Spread (bentang) antara suku bunga pinjaman dan simpanan merupakan salah satu indikator menilai efisiensi intermediasi keuangan". ${ }^{40}$ Khususnya bank muamalat Indonesia diharapkan dapat terus memperkecil rasio BOPO nya yang pada periode penelitian ini rata-rata sebesar 90,76\%, berada pada peringkat 5 menurut kriteria penilaian peringkat sangat sensitif, dengan upaya mengoptimalkan segala sumber daya (resources), sehingga operasional bank bersangkutan akan semakin efisien untuk mendapatkan profit dan dalam melakukan aktifitasnya tidak terganggu.

Pengaruh kecukupan modal (CAR) yang belum signifikan terhadap profitabilitas bank muamalat tetap harus menjadi perhatian pihak manajemen bank, hal ini dikarenakan pola hubungan yang negatif jika berlanjut dalam jangka panjang berpotensi untuk mengurangi kesempatan bank muamalat dalam meraih profit. Untuk itu manajemen bank diharapkan selalu menjaga tingkat kecukupan modalnya, meminimalkan risiko pembiayaan bermasalah dan menjaga efisiensi operasional, sehingga akan meningkatkan kinerja keuangan bank tersebut. Dengan demikian diharapkan bank mampu menyediakan dana untuk keperluan ekspansi (pengembangan) usaha untuk meningkatkan profit.

\section{Bibliografi}

Abdillah, R., Hosen, M. N., \& Muhari, S. The Determinants Factor of Islamic Bank's Profitability and Liquidity in Indonesia. Knowledge Horizons. Economics, 8(2), 2016.

Chowdhury, M. A. F., \& Rasid, M. E. S. M. (2015). The determinants of the profitability of Islamic banks: a cross-sectional study from Asia and Africa. International Journal of Business and Globalisation, 15(3), 2015. HIm. 375-388.

Defri. "Pengaruh Capital Adequacy Ratio (CAR), Likuiditas dan Efisiensi Operasional Terhadap Profitabilitas Perusahaan Perbankan yang Terdaftar di BEI". Jurnal Manajemen, Volume 01, Nomor 01

Dabla-Noris \& Floerkemeier, (2007). Diakses melalui https://tirto.id/bankbank-di-indonesia-belum-efisien-dan-cari-untung-besar-cQdH. tgl 27 Aprl 2019

${ }^{40}$ Dabla-Noris \& Floerkemeier, (2007). Diakses melalui https://tirto.id/bank-bank-diindonesia-belum-efisien-dan-cari-untung-besar-cQdH. tgl 27 Aprl 2019 
Dendawijaya Lukman. Manajemen Perbankan, Jakarta: Ghalia Indonesia, 2003.

Fenandi Bilian dan Purwanto. Analisis Pengaruh CAR, NIM, BOPO, dan LDR Terhadap Profitabilitas Bank Persero. FIRM Journal of Managemen Studies. Vol 2, No 1. 2017, Hlm. 155 - 168.

Imam Ghozali, Aplikasi Analisis Multivariate Dengan Program SPSS. Semarang: Badan Penerbit Universitas Diponegoro, 2012.

Johar Manikam dan Muchamad Syafruddin. Analisis Pengaruh Capital Adequacy Ratio (CAR), Net Interest Margin (NIM), Loan to Deposit Ratio (LDR) dan BOPO Terhadap Profitabilitas Bank Persero di Jambi Periode 2005-2012. Volume 2, Nomor 4, 2013, Hlm. 1-10.

Kasmir, Dasar-Dasar perbankan, Edisi Revisi, Jakarta: Raja Grafindo Persada, 2012.

Kasmir, Manajemen Perbankan, Jakarta: Raja Grafindo Persada, 2004.

Lemiyana dan Erdah Litriani. Pengaruh NPF, FDR, BOPO Terhadap Return on Asset (ROA) pada Bank Umum Syariah. Economic Vol. 2. No.1, 2016.

Lenny Yanthiani. Pengaruh Non-Performing Financing (NPF) dan Financing to Deposit rtio (FDR) Terhadap Return on asset (ROA) di PT. bank Jabar Banten Syariah Kantor Pusat. Jurnal Akuntansi Bisnis dan Ekonomi Volume 5 No. 1, 2019.

Muhammad Yusuf Wibisono dan Salamah Wahyuni. (2017). Pengaruh CAR, NPF, BOPO, FDR, Terhadap ROA yang dimediasi oleh NOM. Jurnal Bisnis \& Manajemen Vol. 17, No. 1, 2017. Hlm. 41-62.

Medina Almunawwaroh. Analisis pengaruh kecukupan modal, kualitas aktiva produktif dan likuiditas terhadap kinerja bank umum syariah di Indonesia Jurnal Akuntansi Vol 12, Nomor 1, 2017. Hlm.. 69-84.

Ningsukma Hakiim dan Haqiqi Rafsanjani. Pengaruh Internal Capital Adequency Ratio (CAR), Financing to Deposit Ratio (FDR), dan Biaya Operasional per Pendapatan Operasional (BOPO) dalam Peningkatan Profitabilitas Industri Bank di Indonesia. Jurnal Perbankan Syariah Vol. 1 No. 1, 2016.

Ponttie Prasnanugraha. Analisis Pengaruh Rasio-rasio Keuangan Terhadap Kinerja Bank Umum di Indonesia (Studi Empiris Bank-bank Umum Yang Beroperasi Di Indonesia. Tesis, 2007.

Sri Windarti Mokoagow dan Misbach Fuady. Faktor-Faktor yang Mempengaruhi Profitabilitas Bank Umum Syariah di Indonesia. Jurnal EBBANK Vol.6, No. 1, 2015, Hlm. 33-62.

Tarmizi Achmad dan Willyanto Kartiko Kusuno. Analisis Rasio-rasio Keuangan Sebagai Prediktor Dalam Memprediksi Potensi Kebangkrutan Perbankan di Indonesia, Media Ekonomi dan Bisnis, Vol. XV, NO. 1, 2003.

Yuliani. Hubungan Efisiensi Operasional dengan Kinerja Profitabilitas pada Sektor Perbankan yang GO Publik di Bursa Efek Jakarta. Jurnal Manajemen \& Bisnis Sriwijaya Vol. 5 No 10, 2007. 